\title{
Rapid detection of Pseudomonas aeruginosa from positive blood cultures by quantitative PCR
}

\author{
Vincent Cattoir ${ }^{1,2^{*}}$, Audrey Gilibert ${ }^{1}$, Jeanne-Marie Le Glaunec ${ }^{1}$, Nathalie Launay ${ }^{1}$, Lilia Bait-Mérabet ${ }^{1}$, \\ Patrick Legrand ${ }^{1}$
}

\begin{abstract}
Background: Pseudomonas aeruginosa is responsible for numerous bloodstream infections associated with severe adverse outcomes in case of inappropriate initial antimicrobial therapy. The present study was aimed to develop a novel quantitative PCR (qPCR) assay, using ecfX as the specific target gene, for the rapid and accurate identification of $P$. aeruginosa from positive blood cultures (BCs).
\end{abstract}

Methods: Over the period August 2008 to June 2009, 100 BC bottles positive for gram-negative bacilli were tested in order to evaluate performances of the qPCR technique with conventional methods as gold standard (i.e. culture and phenotypic identification).

Results: Thirty-three strains of P. aeruginosa, 53 strains of Enterobactericaeae, nine strains of Stenotrophomonas maltophilia and two other gram-negative species were isolated while 3 BCs were polymicrobial including one mixture containing $P$. aeruginosa. All $P$. aeruginosa clinical isolates were detected by qPCR except a single strain in mixed culture. Performances of the qPCR technique were: specificity, 100\%; positive predictive value, 100\%; negative predictive value, 98.5\%; and sensitivity, 97\%.

Conclusions: This reliable technique may offer a rapid $(<1.5 \mathrm{~h})$ tool that would help clinicians to initiate an appropriate treatment earlier. Further investigations are needed to assess the clinical benefit of this novel strategy as compared to phenotypic methods.

\section{Background}

Pseudomonas aeruginosa is a major human opportunistic pathogen responsible for numerous nosocomial infections, especially within intensive care units [1]. In US hospital settings, P. aeruginosa is the seventh (i.e. 4.3\%) most frequently isolated pathogen from the bloodstream, with a crude mortality exceeding 25\% [2]. Although rarely responsible for community-acquired infections, $P$. aeruginosa represents $6.8 \%$ of bacteremia caused by gram-negative rods [3]. Since $P$. aeruginosa bacteremia is clinically indistinguishable from other gram-negative bacterial bloodstream infections, it has been demonstrated that an inappropriate initial antimicrobial therapy was associated with severe adverse outcomes [4-6].

\footnotetext{
* Correspondence: cattoir-v@chu-caen.fr

'Laboratoire de Bactériologie-Virologie-Hygiène, Hôpital Henri Mondor,

Assistance Publique-Hôpitaux de Paris, Créteil, France Full list of author information is available at the end of the article
}

Because standard phenotypic methods are time consuming and most have inherent limitations, molecular techniques have shown to be a rapid and reliable approach for the identification of bacterial pathogens [7]. Therefore, several PCR-based methods have already been described to identify $P$. aeruginosa, especially in respiratory samples from cystic fibrosis patients. Different molecular targets have been employed such as $16 \mathrm{~S}$ rRNA, algD, oprI, oprL, tox $A$, gyrB, and ecf $X$ genes [8-13]. Since false-positive results (with $16 \mathrm{~S}$ rRNA and oprI genes) as well as falsenegative results (with $\operatorname{alg} D$ and toxA genes) have been reported, the ecf $X$ gene is a suitable target for speciesspecific identification of $P$. aeruginosa isolates $[11,13]$.

While identification of $P$. aeruginosa from a positive blood culture (BC) takes at least $24 \mathrm{~h}$ using conventional techniques, molecular identification directly from positive BCs could be an interesting alternative leading to a rapid and accurate species-level identification with subsequent adequate empirical treatment. However, PCR detection of $P$. aeruginosa from positive BCs has
Ciomed Central 
been poorly investigated [14,15], and the authors used oprI and oprL as target genes, described previously as non- $100 \%$ specific $[8,11]$.

In this study, we have developed a novel quantitative PCR (qPCR) assay, using ecf $X$ as the specific target gene, for the rapid and accurate identification of $P$. aeruginosa from positive $\mathrm{BCs}$

\section{Methods}

\section{Clinical specimens and phenotypic identification}

From August 2008 to June 2009, a total of 100 positive BCs from 100 inpatients were included. For each patient, a pair of aerobic (BacT/ALERT FA) and anaerobic (BacT/ALERT FN) bottles was taken, then incubated in the BacT/ALERT automated continuous monitoring system (bioMérieux, Marcy-l'Etoile, France). The distribution of positive BCs by bottle type was as follows: 87 aerobic (87\%) and 13 (13\%) anaerobic. All these BCs showed gram-negative rods at the direct examination, and most of them presented a Gram-staining and/or a motility compatible with those of the species $P$. aeruginosa. Positive bottles were inoculated aerobically and anaerobically at $37^{\circ} \mathrm{C}$ for $24-48 \mathrm{~h}$ onto trypticase-soy agar, Drigalski agar, $5 \%$ horse blood agar and chocolate agar plates, and the concentration of bacteria was determined by quantitative culture (10-fold serial dilutions from $10^{-1}$ to $10^{-10}$ ). Strains were identified by colony morphology, oxidase reaction, and results of the API 20 E system (bioMérieux).

\section{DNA extraction}

From a $0.5-\mathrm{ml}$ aliquot of blood, template DNA was prepared by using a simple and rapid boiling procedure, taking less than 20 min $[16,17]$. Briefly, the aliquot was centrifuged at $850 \times \mathrm{g}$ for $2 \mathrm{~min}$ to remove the charcoal. The supernatant was centrifuged at $11,500 \times \mathrm{g}$ for $5 \mathrm{~min}$. The resulting pellet was resuspended in $200 \mu \mathrm{l}$ of a lysis buffer containing $1 \%$ Triton X-100, 0.5\% Tween 20, $10 \mathrm{mM}$ Tris$\mathrm{Hcl}(\mathrm{pH} 8.0)$, and $1 \mathrm{mM}$ EDTA and incubated at $100^{\circ} \mathrm{C}$ for $10 \mathrm{~min}$. After centrifugation for $2 \mathrm{~min}$ at $850 \times \mathrm{g}$, the supernatant was directly used for PCR.

\section{Quantitative PCR}

The qPCR assay was performed with the LightCycler v.2.0 instrument (Roche, Meylan, France). Oligonucleotide primers and fluorescent-labeled hybridization probes were designed for amplification and sequence-specific detection of a 152-bp fragment within the ecf $X$ gene (Table 1). The amplification mixture consisted of $2 \mu \mathrm{l}$ of $10 \times$ LightCycler FastStart DNA Master Hybridization Probes mixture (Roche), $2 \mathrm{mM} \mathrm{MgCl} 2,0.5 \mu \mathrm{M}$ each primer, $0.2 \mu \mathrm{M}$ each probe, and $5 \mu \mathrm{l}$ of template DNA in a final volume of 20 $\mu l$. A suspension of Tris-EDTA and a DNA extract of $P$. aeruginosa ATCC 27853 were used as negative and positive controls, respectively. Following an initial denaturation at $95^{\circ} \mathrm{C}$ for $10 \mathrm{~min}$, the 45 -cycle amplification profile consisted of heating a $95^{\circ} \mathrm{C}$ segment for $10 \mathrm{~s}$, a $50^{\circ} \mathrm{C}$ segment for $10 \mathrm{~s}$, and a $72^{\circ} \mathrm{C}$ segment for $20 \mathrm{~s}$. The presence of amplified DNA was measured by detection of emitted fluorescence at $705 \mathrm{~nm}$, and the final result was available in $\sim 1.5 \mathrm{~h}$. In parallel, PCR inhibition control was performed for all samples in the same run by using a second reaction tube containing $100 \mathrm{ng}$ of DNA extract from the positive control.

\section{Limit of detection}

A plasmid standard curve was constructed by ligating the 152-bp PCR product from P. aeruginosa ATCC 27853 into the commercial plasmid vector, pCR2.1TOPO plasmid vector from the TOPO TA Cloning Kit (Invitrogen, Cergy-Pontoise, France) following the manufacturer's recommendations to produce plasmid pRTecfX. This plasmid was transformed into competent TOP10 Escherichia coli cells (Invitrogen), and transformants were selected on media containing $30 \mu \mathrm{g} / \mathrm{mL}$ kanamycin. Plasmid DNA was extracted and purified from one transformant using the HiSpeed Midi Kit (Qiagen, Valencia, CA) according to the manufacturer's instructions, resuspended in elution buffer (Qiagen) and sequenced to determine the presence of the ecf $X$ insert and its orientation. Plasmid DNA concentration was determined by using the NanoDrop ND-1000 spectrophotometer (Thermo Scientific, Illkirch, France), and the plasmid DNA reference material was then serially diluted to obtain 10 to $10^{10}$ plasmid genome equivalents for standard curve analysis. Quantitative analysis was carried out with the LightCycler software version 3.5 (Roche). The ratio of signals measured at $705 \mathrm{~nm} / \mathrm{sig}$ nals measured at $530 \mathrm{~nm}$ was used to calculate the crossing point values.

Table 1 Oligonucleotide primers and LightCycler hybrizidation probes used in the PCR assay

\begin{tabular}{|c|c|c|c|}
\hline Oligonucleotides & Sequence $\left(5^{\prime}-3^{\prime}\right)$ & Target gene & Nucleotide position \\
\hline$\overline{e c f X-F}$ & TTCCATGGCGAGTTGCT & & $46-62$ \\
\hline ecfX-R & CGGGCGATCTGGAAAAGAA & & 179-197 \\
\hline ecfX-HP-1 & GCTGAAATGGCCGGGCC-[FAM] & $e c f x^{b}$ & 135-151 \\
\hline ecfX-HP-2 & [LC705]-CAATCGGTCGAGCAGCCGC-Ph & & 154-172 \\
\hline
\end{tabular}

a [FAM], fluorescein; [LC705], LightCycler ${ }^{\text {TM}}$-Red 705; Ph, 3'-phosphate. ${ }^{\text {b }}$ Extracytoplasmic function gene (GenBank accession no. DQ996551). 
Table 2 ecfX qPCR testing of $P$. aeruginosa from 98 positive blood culture bottles

\begin{tabular}{|c|c|c|c|}
\hline \multirow[t]{2}{*}{ Organisms } & \multicolumn{2}{|c|}{ No. of samples detected } & \multirow[t]{2}{*}{ Total no. of samples } \\
\hline & $\mathrm{PCR}^{+}$ & $\mathrm{PCR}^{-}$ & \\
\hline Pseudomonas aeruginosa & 33 & 0 & 33 \\
\hline Escherichia coli & 0 & 21 & 21 \\
\hline Stenotrophomonas maltophilia & 0 & 9 & 9 \\
\hline Klebsiella pneumoniae & 0 & 8 & 8 \\
\hline Enterobacter cloacae & 0 & 7 & 7 \\
\hline Citrobacter koseri & 0 & 4 & 4 \\
\hline Enterobacter aerogenes & 0 & 3 & 3 \\
\hline Proteus mirabilis & 0 & 3 & 3 \\
\hline Morganella morganii & 0 & 3 & 3 \\
\hline Serratia marcescens & 0 & 1 & 1 \\
\hline Pantoea spp. & 0 & 1 & 1 \\
\hline Brevundimonas diminuta & 0 & 1 & 1 \\
\hline Bacteroides fragilis & 0 & 1 & 1 \\
\hline E. coli + Klebsiella oxytoca ${ }^{a}$ & 0 & 1 & 1 \\
\hline E. cloacae $+K$. oxytoca ${ }^{a}$ & 0 & 1 & 1 \\
\hline K. pneumoniae $+\boldsymbol{P}$. aeruginosa $a^{a, b}$ & 0 & 1 & 1 \\
\hline
\end{tabular}

${ }^{a}$ Polymicrobial blood cultures. ${ }^{b}, 20 \mathrm{CFU} / \mathrm{ml}$ of $P$. aeruginosa and $10^{8} \mathrm{CFU} / \mathrm{ml}$ of $K$. pneumoniae were recovered by quantitative culture.

\section{Results}

Culture of the $100 \mathrm{BCs}$ isolated 33 strains of P. aeruginosa (including 2 recovered in anaerobic bottles), 53 strains of Enterobacteriaceae (including 22 Escherchia coli), 9 strains of Stenotrophomonas maltophilia, 2 other gram-negative species, and $3 \mathrm{BCs}$ were polymicrobial of which one mixture of Klebsiella pneumoniae and $P$. aeruginosa (Table 2). Note that the presence of PCR inhibition was observed only for two (2\%) DNA preparations. Out of the 95 monomicrobial cultures, the real-time ecfX PCR assay was $100 \%$ sensitive and $100 \%$ specific for detecting $P$. aeruginosa. However, the PCR assay could not detect the presence of $P$. aeruginosa in a single polymicrobial culture with $K$. pneumoniae. By performing the PCR assay directly from the $P$. aeruginosa isolate, we could amplify ecf $X$, demonstrating that this problem was not due to an absence or a sequence variation of the gene. By quantitative culture, we found that the concentration of $P$. aeruginosa in this $\mathrm{BC}$ was very low $(20 \mathrm{CFU} / \mathrm{ml})$ as compared with that of $K$. pneumoniae $\left(10^{8} \mathrm{CFU} / \mathrm{ml}\right)$. Limit of detection was estimated at $10^{2} \mathrm{CFU} / \mathrm{ml}$ (Fig. 1 and Fig. 2) leading that the absence of signal by PCR could be explained by a default of sensitivity in this peculiar case. Taken into account the $98 \mathrm{BCs}$ with interpretable results (98\%), the qPCR assay showed $100 \%$ of specificity and PPV, $98.5 \%$ of NPV, and $97 \%$ of sensitivity.

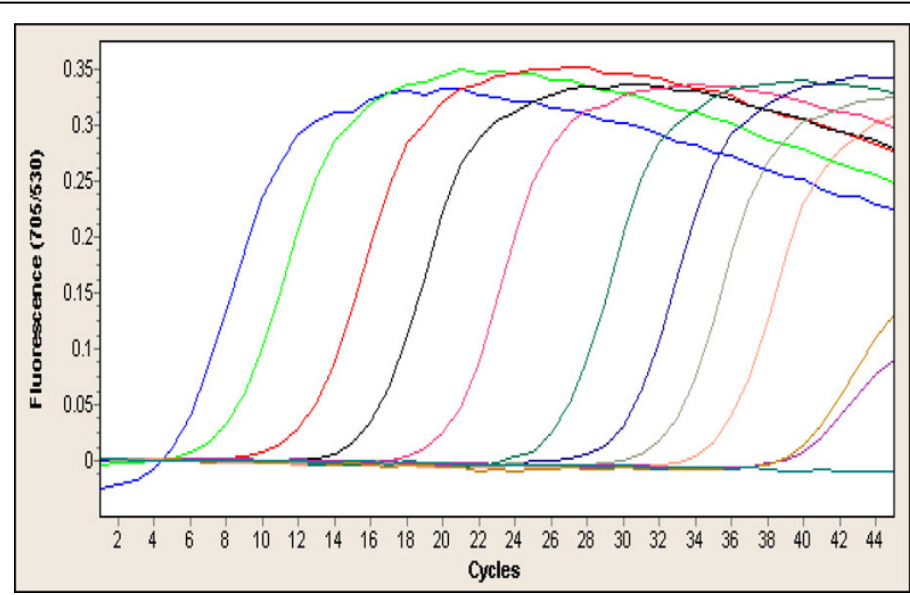

$10^{11}$ copies $/ \mathrm{ml}$

$10^{10}$ copies $/ \mathrm{ml}$

$10^{9}$ copies $/ \mathrm{ml}$

$10^{8}$ copies $/ \mathrm{ml}$

$10^{7}$ copies $/ \mathrm{ml}$

$10^{6}$ copies $/ \mathrm{ml}$

$10^{5}$ copies $/ \mathrm{ml}$

$10^{4}$ copies $/ \mathrm{ml}$

$10^{3}$ copies $/ \mathrm{ml}$

$10^{2}$ copies $/ \mathrm{ml}$

10 copies $/ \mathrm{ml}$

Negative control

Figure 1 qPCR amplification curves of plasmid DNA reference material with 11 external DNA concentrations (from $10^{11}$ to 10 copies/ $\mathrm{ml})$. 


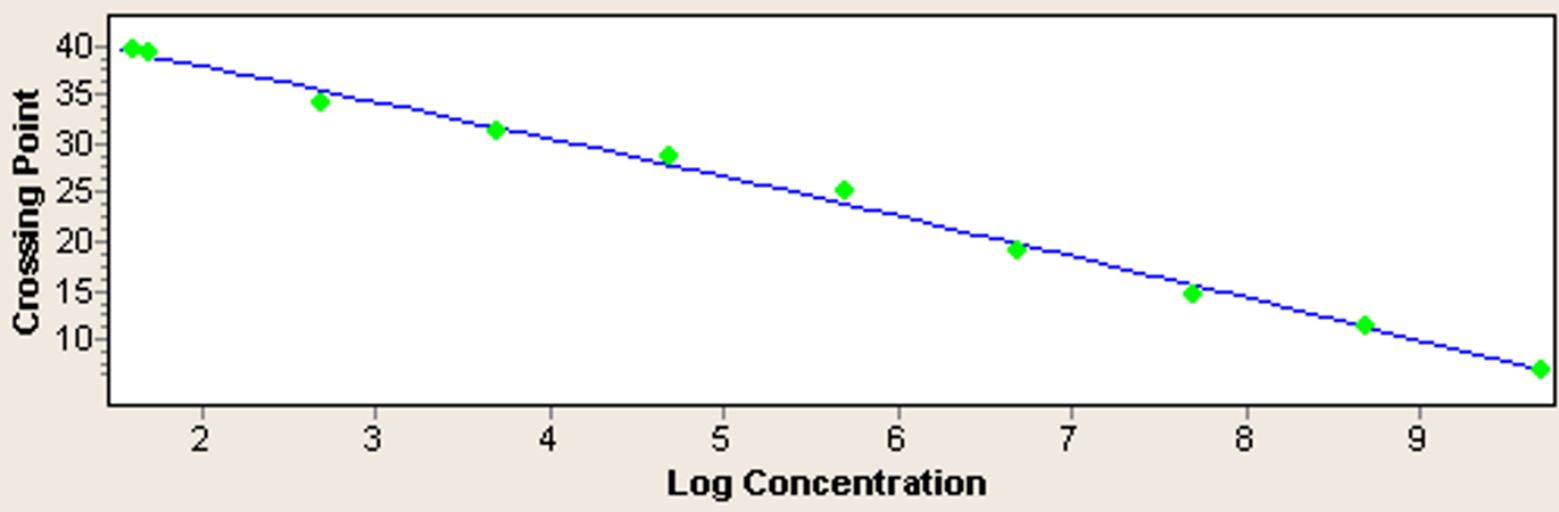

Figure 2 Calibration curve of qPCR using serial dilutions of plasmid DNA reference material (see Figure 1).

\section{Discussion}

Even if the motility in an aerobic bottle may be a good predictive value of $P$. aeruginosa isolation, the observation of non-motile rods or atypical motility is regularly observed [18] as well as the growth of this aerobe in anaerobic bottles (6\% in our study) [19]. By comparison with the new FDA-approved technique (i.e. fluorescence in situ hybrizidation with peptide nucleic acid probes) directly used on positive BCs, this novel qPCR method showed similar performances but appeared faster $(1.5 \mathrm{~h}$ vs $2.5 \mathrm{~h})[20,21]$. Nevertheless, a limit of the qPCR technique is the potential presence of PCR inhibitors (e.g. charcoal, haemoglobin) in $\mathrm{BC}$ specimens.

The timely and accurate information provided by this qPCR assay would help clinicians identify $P$. aeruginosa bacteremia, and thereby initiate adequate antimicrobial therapy 18 to $24 \mathrm{~h}$ earlier than would be possible with conventional methods, as previously described for Staphylococcus aureus [16,17] and K. pneumoniae [22]. However, as opposed to $S$. aureus and methicillin resistance, it is difficult to predict an useful antibiotic susceptibility profile of $P$. aeruginosa by molecular techniques even if it is possible to detect several resistance genes such as emerging carbapenemase genes [7]. Indeed, the choice of antibiotic treatment has to consider national and local epidemiology since multidrug resistant $P$. aeruginosa isolates are increasingly reported worldwide [23]. Therefore, in order to minimize the risk of inappropriate treatment, the use of combination antimicrobial therapy, until susceptibility results become known, may be preferable in certain situations $[5,6]$.

\section{Conclusions}

As a conclusion, we developed a promising qPCR technique that offers a fast $(<1.5 \mathrm{~h})$ tool with high sensitivity and specificity for the identification of $P$. aeruginosa from positive BCs. Further investigations will be perform to evaluate the clinical impact of this novel strategy as compared to conventional methods.

\section{Author details}

${ }^{1}$ Laboratoire de Bactériologie-Virologie-Hygiène, Hôpital Henri Mondor, Assistance Publique-Hôpitaux de Paris, Créteil, France. ${ }^{2}$ Laboratoire de Microbiologie, CHU Côte de Nacre, Caen, France.

\section{Authors' contributions}

Each author acknowledges that he has contributed in a substantial way to the work described in the manuscript and its preparation. All authors have read and approved the final manuscript.

\section{Competing interests}

The authors declare that they have no competing interests.

Received: 17 March 2010 Accepted: 4 August 2010

Published: 4 August 2010

\section{References}

1. Driscoll JA, Brody SL, Kollef MH: The epidemiology, pathogenesis and treatment of Pseudomonas aeruginosa infections. Drugs 2007, 67:351-368.

2. Wisplinghoff $H$, Bischoff $T$, Tallent SM, Seifert $H$, Wenzel RP, Edmond MB: Nosocomial bloodstream infections in US hospitals: analysis of 24,179 cases from a prospective nationwide surveillance study. Clin Infect Dis 2004, 39:309-317.

3. Schechner V, Nobre V, Kaye KS, Leshno M, Giladi M, Rohner P, Harbarth S, Anderson DJ, Karchmer AW, Schwaber MJ, et al: Gram-negative bacteremia upon hospital admission: when should Pseudomonas aeruginosa be suspected? Clin Infect Dis 2009, 48:580-586.

4. Kang Cl, Kim SH, Kim HB, Park SW, Choe YJ, Oh MD, Kim EC, Choe KW: Pseudomonas aeruginosa bacteremia: risk factors for mortality and influence of delayed receipt of effective antimicrobial therapy on clinical outcome. Clin Infect Dis 2003, 37:745-751.

5. Micek ST, Lloyd AE, Ritchie DJ, Reichley RM, Fraser VJ, Kollef MH: Pseudomonas aeruginosa bloodstream infection: importance of appropriate initial antimicrobial treatment. Antimicrob Agents Chemother 2005, 49:1306-1311.

6. van Delden C: Pseudomonas aeruginosa bloodstream infections: how should we treat them? Int J Antimicrob Agents 2007, 30(Suppl 1):S71-75.

7. Procop GW: Molecular diagnostics for the detection and characterization of microbial pathogens. Clin Infect Dis 2007, 45(Suppl 2):S99-S111.

8. De Vos D, Lim A Jr, Pirnay JP, Struelens M, Vandenvelde C, Duinslaeger L, Vanderkelen A, Cornelis P: Direct detection and identification of Pseudomonas aeruginosa in clinical samples such as skin biopsy specimens and expectorations by multiplex PCR based on two outer membrane lipoprotein genes, oprl and oprL. J Clin Microbiol 1997, 35:1295-1299. 
9. Qin X, Emerson J, Stapp J, Stapp L, Abe P, Burns JL: Use of real-time PCR with multiple targets to identify Pseudomonas aeruginosa and other nonfermenting gram-negative bacilli from patients with cystic fibrosis. J Clin Microbiol 2003, 41:4312-4317.

10. da Silva Filho LV, Tateno AF, Velloso Lde F, Levi JE, Fernandes S, Bento CN, Rodrigues JC, Ramos SR: Identification of Pseudomonas aeruginosa, Burkholderia cepacia complex, and Stenotrophomonas maltophilia in respiratory samples from cystic fibrosis patients using multiplex PCR. Pediatr Pulmonol 2004, 37:537-547.

11. Lavenir R, Jocktane D, Laurent F, Nazaret S, Cournoyer B: Improved reliability of Pseudomonas aeruginosa PCR detection by the use of the species-specific ecfX gene target. J Microbiol Methods 2007, 70:20-29.

12. Motoshima M, Yanagihara K, Fukushima K, Matsuda J, Sugahara K, Hirakata Y, Yamada Y, Kohno S, Kamihira S: Rapid and accurate detection of Pseudomonas aeruginosa by real-time polymerase chain reaction with melting curve analysis targeting gyrB gene. Diagn Microbiol Infect Dis 2007, 58:53-58.

13. Anuj SN, Whiley DM, Kidd TJ, Bell SC, Wainwright CE, Nissen MD, Sloots TP: Identification of Pseudomonas aeruginosa by a duplex real-time polymerase chain reaction assay targeting the ecfX and the gyrB genes. Diagn Microbiol Infect Dis 2009, 63:127-131.

14. Jaffe RI, Lane JD, Bates CW: Real-time identification of Pseudomonas aeruginosa direct from clinical samples using a rapid extraction method and polymerase chain reaction (PCR). J Clin Lab Anal 2001, 15:131-137.

15. Kurupati P, Kumarasinghe G, Laa Poh C: Direct identification of Pseudomonas aeruginosa from blood culture bottles by PCR-enzyme linked immunosorbent assay using oprl gene specific primers. Mol Cell Probes 2005, 19:417-421.

16. Reischl U, Linde HJ, Metz M, Leppmeier B, Lehn N: Rapid identification of methicillin-resistant Staphylococcus aureus and simultaneous species confirmation using real-time fluorescence PCR. J Clin Microbiol 2000, 38:2429-2433

17. Shrestha NK, Tuohy MJ, Hall GS, Isada CM, Procop GW: Rapid identification of Staphylococcus aureus and the mecA gene from BacT/ALERT blood culture bottles by using the LightCycler system. J Clin Microbiol 2002, 40:2659-2661.

18. Schonheyder HC, Pedersen G: Pseudomonas aeruginosa bacteraemia detected with a new blood culture system Colorbact: a note of caution. Apmis 1993, 101:732-734.

19. Enoch DA, Simpson AJ, Kibbler CC: Predictive value of isolating Pseudomonas aeruginosa from aerobic and anaerobic blood culture bottles. J Med Microbiol 2004, 53:1151-1154.

20. Sogaard M, Stender H, Schonheyder HC: Direct identification of major blood culture pathogens, including Pseudomonas aeruginosa and Escherichia coli, by a panel of fluorescence in situ hybridization assays using peptide nucleic acid probes. J Clin Microbiol 2005, 43:1947-1949.

21. Peleg AY, Tilahun Y, Fiandaca MJ, D'Agata EM, Venkataraman $L$, Moellering RC, Eliopoulos GM: Utility of peptide nucleic acid fluorescence in situ hybridization for rapid detection of Acinetobacter spp. and Pseudomonas aeruginosa. J Clin Microbiol 2009, 47:830-832.

22. Kurupati P, Chow C, Kumarasinghe G, Poh CL: Rapid detection of Klebsiella pneumoniae from blood culture bottles by real-time PCR. J Clin Microbiol 2004, 42:1337-1340.

23. Nordmann P, Naas T, Fortineau N, Poirel L: Superbugs in the coming new decade; multidrug resistance and prospects for treatment of Staphylococcus aureus, Enterococcus spp. and Pseudomonas aeruginosa in 2010. Curr Opin Microbiol 2007, 10:436-440.

doi:10.1186/1476-0711-9-21

Cite this article as: Cattoir et al:: Rapid detection of Pseudomonas aeruginosa from positive blood cultures by quantitative PCR. Annals of Clinical Microbiology and Antimicrobials 2010 9:21.

\section{Submit your next manuscript to BioMed Central and take full advantage of:}

- Convenient online submission

- Thorough peer review

- No space constraints or color figure charges

- Immediate publication on acceptance

- Inclusion in PubMed, CAS, Scopus and Google Scholar

- Research which is freely available for redistribution

Submit your manuscript at www.biomedcentral.com/submit
Biomed Central 